Correspondence

Heung-Shick Lee

hlee@korea.ac.kr

Received 9 October 2008

Revised 4 March 2009

Accepted 6 March 2009

\section{The cmaR gene of Corynebacterium ammoniagenes performs a novel regulatory role in the metabolism of sulfur-containing amino acids}

\author{
Seok-Myung Lee, ${ }^{1}$ Byung-Joon Hwang, ${ }^{2}$ Younhee $\mathrm{Kim}^{3}$ \\ and Heung-Shick Lee ${ }^{1}$ 339-700, Republic of Korea
${ }^{2}$ R\&D Center, Daesang Co. 125-8, Pyokyo-Ri, Majang-Myun, Ichon, Kyoungki 467-813, Republic of Korea
${ }^{3}$ Department of Oriental Medicine, Semyung University, Checheon, Chungbuk 390-230, Republic of Korea \\ ${ }^{1}$ Department of Biotechnology and Bioinformatics, Korea University, Jochiwon, Chungnam
}

\begin{abstract}
A novel regulatory gene, which performs an essential function in sulfur metabolism, has been identified in Corynebacterium ammoniagenes and was designated $c m a R$ (cysteine and methionine regulator in $C$. ammoniagenes). The $c m a R$-disrupted strain $(\Delta c m a R)$ lost the ability to grow on minimal medium, and was identified as a methionine and cysteine double auxotroph. The mutant strain proved unable to convert cysteine to methionine (and vice versa), and lost the ability to assimilate and reduce sulfate to sulfide. In the $\Delta c m a R$ strain, the mRNAs of the methionine biosynthetic genes met $Y X$, metB and metFE were significantly reduced, and the activities of the methionine biosynthetic enzymes cystathionine $\gamma$-synthase, $O$-acetylhomoserine sulfhydrylase, and cystathionine $\beta$-lyase were relatively low, thereby suggesting that the cmaR gene exerts a positive regulatory effect on methionine biosynthetic genes. In addition, with the exception of $c y s K$, reduced transcription levels of the sulfur-assimilatory genes $c y s I X Y Z$ and $c y s H D N$ were noted in the cmaR-disrupted strain, which suggests that sulfur assimilation is also under the positive control of the cmaR gene. Furthermore, the expression of the $c m a R$ gene itself was strongly induced via the addition of cysteine or methionine alone, but not the introduction of both amino acids together to the growth medium. In addition, the expression of the cmaR gene was enhanced in an $m c b R$-disrupted strain, which suggests that $c m a R$ is under the negative control of $\mathrm{McbR}$, which has been identified as a global regulator of sulfur metabolism. DNA binding of the purified CmaR protein to the promoter region of its target genes could be demonstrated in vitro. No metabolite effector was required for the protein to bind DNA. These results demonstrated that the cmaR gene of $C$. ammoniagenes plays a role similar to but distinct from that of the functional homologue cys $R$ of Corynebacterium glutamicum.
\end{abstract}

\section{INTRODUCTION}

Sulfur is indispensable to the growth of micro-organisms. It is a critical component of the amino acids cysteine and methionine. Moreover, cysteine-derived proteins such as

Abbreviations: OAH, O-acetyl-L-homoserine; OAS, O-acetyl-L-serine; $\mathrm{SAH}, \mathrm{S}$-adenosyl-L-homocysteine; SAM, S-adenosyl-L-methionine.

The GenBank/EMBL/DDBJ accession numbers for the $c m a R$, metYX, metFE, metB, cysIXYZ, cysHDN, cysKE, mcbR and aecD sequences of Corynebacterium ammoniagenes are FJ210287, FJ483537, FJ483538, FJ483539, FJ483540, FJ483541, FJ483542, FJ483543 and FJ483544, respectively.

A supplementary table, listing primers used in this study, is available with the online version of this paper. thioredoxin participate in a number of critical cellular defence processes against oxidative stress. The sulfur moiety of cysteine is synthesized from sulfide, which is generated by the serial reduction of oxidized sulfur sources via a process referred to as 'sulfur assimilation'. The sulfur moiety of methionine is supplied by cysteine (transsulfuration) or sulfide (direct sulfhydrylation) (Fig. 1). Although significant progress has been made with regard to our knowledge of methionine and cysteine biosynthesis in Corynebacterium glutamicum (Lee, 2005; Rückert \& Kalinowski, 2008), current information regarding the interrelation and control of the cysteine and methionine biosynthetic pathways remains relatively limited. Recently, the reverse transsulfuration route, which is exploited in the 


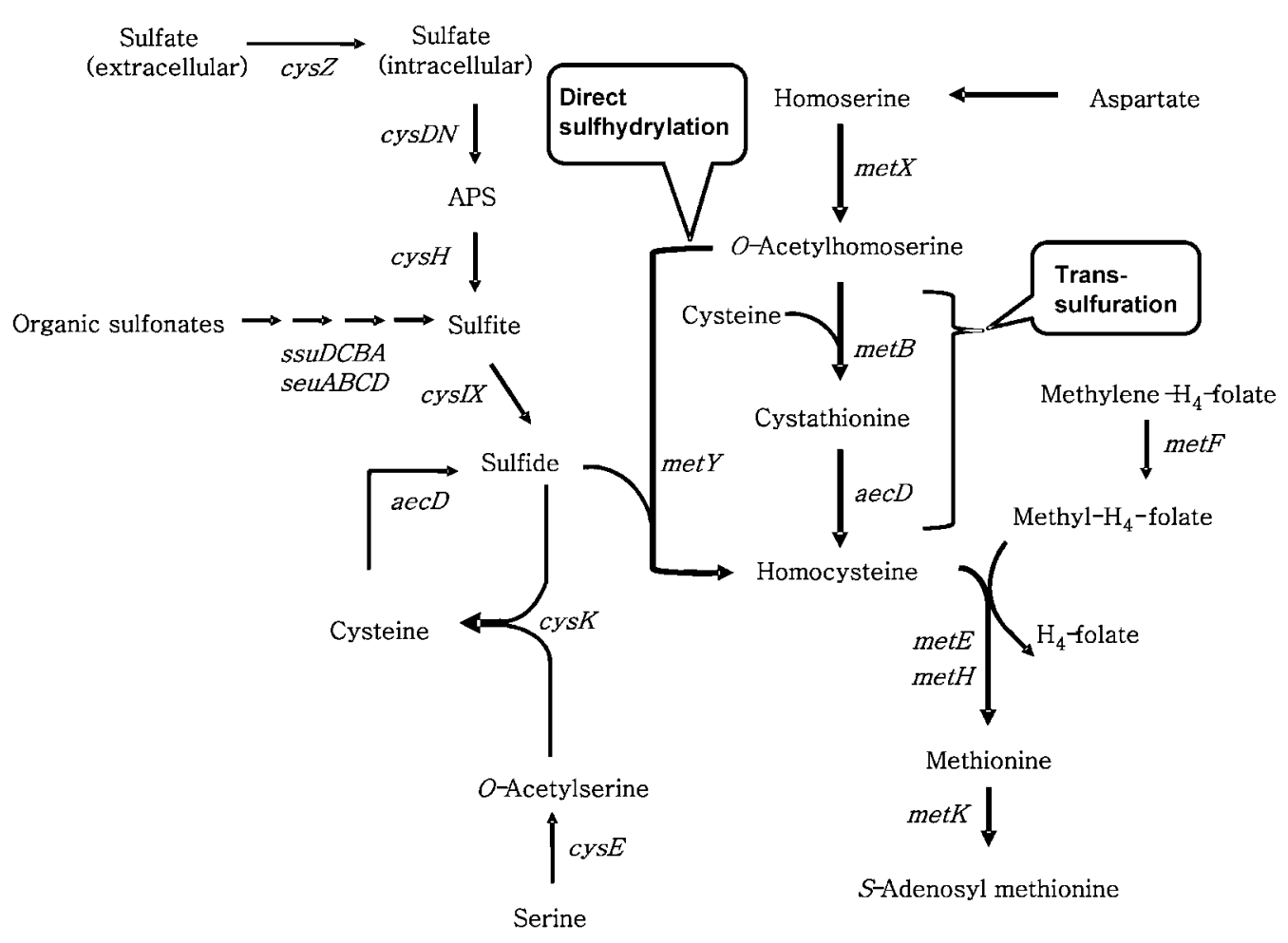

Fig. 1. Biosynthesis of methionine and cysteine in C. glutamicum. The genes encode the following enzymes: cysDN, ATP sulfurylase; $c y s H$, adenosine 5 '-phosphosulfate (APS) reductase; $c y s I X$, sulfite reductase; cysK, $O$-acetylserine thiolase; $c y s E$, serine acetyltransferase; cys $Z$, putative transporter protein; $\operatorname{aec} D$, cysteine desulfhydrase and cystathionine $\beta$-lyase; met $X$, homoserine acetyltransferase; met $B$, cystathionine $\gamma$-synthase; met $Y$, O-acetylhomoserine sulfhydrylase; met $F, N^{5,10}$-methylene $\mathrm{H}_{4}$ reductase; metE, $\mathrm{B}_{12}$-independent methionine synthase; metH, $\mathrm{B}_{12}$-dependent methionine synthase; metK, S-adenosyl methionine synthase; ssuD, $\mathrm{FMNH}_{2}$-dependent aliphatic sulfonate monooxygenase; ssuCBA, ABC-type aliphatic sulfonate transporter; seuAB, $\mathrm{FMNH}_{2}$-dependent monooxygenase, sulfonate ester degrading; seuC, probable $\mathrm{FMNH}_{2}$-dependent monooxygenase.

conversion of methionine to cysteine, has been identified in Bacillus subtilis and Mycobacterium tuberculosis (Hullo et al., 2007; Wheeler et al., 2005). Furthermore, in Pseudomonas putida, methionine is probably utilized to synthesize cysteine via the unusual intermediate methanesulfonate (Vermeij \& Kertesz, 1999). In Corynebacterium, despite its importance as a possible methionine or cysteine producer, the method by which methionine and cysteine are metabolized as a sole sulfur source remains to be clearly elucidated. Therefore, not only experimental corroboration but also in silico prediction from full genome sequences has been utilized to identify the genes involved in sulfur metabolism (Haitani et al., 2006; Hwang et al., 1999, 2002; Kim et al., 2001; Koch et al., 2005a, b; Lee, 2005; Park et al., 1998; Rückert et al., 2003, 2005, 2008; Rey et al., 2003, 2005; Wada et al., 2002, 2004). Significant progress has been made toward understanding the regulatory mechanisms of sulfur metabolism in micro-organisms. In general, sulfur metabolism is strictly regulated by activators and repressors. Thus far, several different types of regulators that control sulfur metabolism in micro-organisms have been identified. In Escherichia coli, CysB activates the transcription of genes associated with cysteine biosynthesis (Kredich, 1996). Under sulfate-starvation conditions, $c b l$, the transcription of which is also positively regulated by $\mathrm{CysB}$, is expressed and, in turn, the gene product activates the transcription of genes involved in taurine and organic sulfur utilization (van der Ploeg et al., 2001). In B. subtilis, CymR plays an important role (Even et al., 2006). Under excess cysteine conditions, CymR forms a complex with CysK and, subsequently, the complex represses genes that participate in cysteine biosynthesis (Hullo et al., 2007). OAcetylserine is a key substance that controls the formation of the CymR-CysK complex (Tanous et al., 2008). Lactococcus lactis employs a similar mechanism for the control of genes (Sperandio et al., 2005). In addition, the positive regulatory protein CysL has also been identified in B. subtilis (Guillouard et al., 2002). The regulatory mechanism of sulfur metabolism in C. glutamicum has recently been established (Rückert et al., 2008). It involves a global repressor McbR and the two activators, SsuR and CysR. The activity of McbR is controlled by the intracellular ratio of $S$-adenosyl-L-homocysteine (SAH) and S-adenosyl-L-methionine (SAM) (Rey et al., 2005; 
Suda et al., 2008). Under repressive conditions, the intracellular concentration of SAH, which is synthesized from methionine via SAM, is low. Subsequently, free McbR proteins repress genes by interacting with the regulatory region of the target genes, including $s s u R$ and $c y s R$. Thus, sulfur metabolism including methionine biosynthesis is repressed. However, if the SAH: SAM ratio is high, McbR is inactivated, $c y s R$ is released from repression, and its gene product CysR activates genes associated with sulfur assimilation to supply the sulfur moiety to metabolic pathways. Activation by CysR requires metabolic effectors such as $\mathrm{O}$-acetyl-L-serine (OAS) and $\mathrm{O}$-acetyl-L-homoserine (OAH) (Rückert et al., 2008). SsuR, which is activated by CysR, is involved in the activation of genes responsible for organic sulfur utilization (Koch et al., 2005a). This hierarchical regulatory model shows similarity to that of E. coli involving CysB and Cbl (IwanickaNowicka \& Hryniewicz, 1995; van der Ploeg et al., 1997).

In this study, we assessed the function of the $c y s R$ homologue in Corynebacterium ammoniagenes, a Gram-positive nucleotide-producing bacterium (Liebl, 2006). Based on the phenotypic, biochemical and molecular biological data, we named the $c y s R$ homologue of $C$. ammoniagenes cmaR (cysteine and methionine regulator in C. ammoniagenes). We have shown that the $\mathrm{cmaR}$ gene encodes a positive regulatory protein for genes involved in sulfur assimilation and methionine biosynthesis in $C$. ammoniagenes. Moreover, we demonstrate that the $\mathrm{cmaR}$ gene performs an essential regulatory function in the conversion of methionine to cysteine, and vice versa. We also demonstrate that the mechanism by which the $\mathrm{CmaR}$ protein exerts its regulatory effect is via the control of the expression of the $c m a R$ gene, rather than by modulating the activity of $\mathrm{CmaR}$ through effectors, as is the case for CysR. The clarification of the mechanism underlying the regulation of sulfur metabolism in this strain is expected to prove beneficial to the development of $C$. ammoniagenes strains that generate large quantities of sulfur-containing amino acids.

\section{METHODS}

Bacterial strains, culture conditions, and auxotrophic test. $E$. coli DH10B (Grant et al., 1990) was grown in Luria broth (LB) at $37{ }^{\circ} \mathrm{C}$. C. ammoniagenes ATCC 6872 was used as the wild-type and grown at $30{ }^{\circ} \mathrm{C}$ in $\mathrm{MB}$ (Follettie et al., 1993) or FMCA minimal medium containing the following $\left(\mathrm{g}^{-1}\right)$ : glucose, 20 ; urea, $3 ; \mathrm{NH}_{4} \mathrm{Cl}$, 2; $\mathrm{KH}_{2} \mathrm{PO}_{4}, \quad 1 ; \mathrm{K}_{2} \mathrm{HPO}_{4}, \quad 3$; asparagine, 5; L-cysteine, 0.04; $\mathrm{MnSO}_{4} \cdot \mathrm{H}_{2} \mathrm{O}, 0.001 ; \mathrm{ZnSO}_{4} \cdot 7 \mathrm{H}_{2} \mathrm{O}, 0.001 ; \mathrm{CuSO}_{4} \cdot 2 \mathrm{H}_{2} \mathrm{O}, 2 \times 10^{-4}$; calcium pantothenate, $0.02 ; \mathrm{CaCl}_{2}, 0.01 ; \mathrm{MgSO}_{4}, 0.3 ; \mathrm{FeSO}_{4} .7 \mathrm{H}_{2} \mathrm{O}$, 0.01 ; biotin, $6 \times 10^{-5}$; thiamine- $\mathrm{HCl}, 0.01$. For the preparation of sulfur-free medium (FMCAS), cysteine was omitted from FMCA, and $\mathrm{MgSO}_{4}, \mathrm{MnSO}_{4}, \mathrm{ZnSO}_{4}, \mathrm{CuSO}_{4}$ and $\mathrm{FeSO}_{4}$ were substituted by equimolar quantities of $\mathrm{MgCl}_{2}, \mathrm{MnCl}_{2}, \mathrm{ZnCl}_{2}, \mathrm{CuCl}_{2}$ and $\mathrm{FeCl}_{2}$, respectively. Antibiotics were added at the following concentrations $\left(\mu \mathrm{g} \mathrm{ml}^{-1}\right)$ : ampicillin, 50; chloramphenicol, 30 for E. coli and 10 for C. ammoniagenes; kanamycin, 50 for $E$. coli and 30 for $C$. ammoniagenes. Sulfur sources were added at the appropriate concentrations, as shown in the figures and tables. For the amino acid auxotrophy test, wild-type and HL1168 were streaked onto the
FMCA solid medium containing a combination of amino acids $\left(50 \mu \mathrm{g} \mathrm{ml}^{-1}\right)$ as described elsewhere (Adams \& Kaiser, 1998).

Construction of plasmids and strains. The $C$. ammoniagenes $\triangle c m a R$ mutant strain was constructed according to the method described by Schäfer et al. (1994). The deletion construct for the cmaR gene was generated via crossover PCR (Link et al., 1997). The primary PCR products amplified with cmaR_delF1/cmaR_delR1 and cmaR_delF2/cmaR_delR2 (for primer sequences, see Supplementary Table S1) were employed as templates for secondary PCR. Following HindIII treatment, the PCR fragment was introduced into HindIIIdigested pK19mobsacB (Schäfer et al., 1994). The resultant plasmid, pSL415, was transformed into E. coli ET12567 (MacNeil et al., 1992) and the plasmids from the strain were electro-transformed into $C$. ammoniagenes. Subsequent steps were conducted as described previously (Hwang et al., 2002; Schäfer et al., 1994). After validating chromosomal deletion via PCR, the mutant strain was designated HL1168. Fundamentally identical procedures were employed to construct the $m c b R$-deficient strain, with the exception of the primers, which were $m c b R \_$delF1/mcbR_delR1 and $m c b R \_$delF2/ $m c b R \_d e l R 2$. The $\Delta c m a R \Delta m c b R$ double mutant strain was constructed by deleting the $c m a R$ gene in the $\Delta m c b R$ strain. In order to construct the $c m a R$-restored strain, the cmaR gene amplified with cmaR_compFland cmaR_compR1 was digested with KpnI and ligated to KpnI-digested pMT1 (Follettie et al., 1993). The resultant plasmid, pSL433, was then introduced into HL1168 in order to generate HL1178. To construct a transcriptional fusion of $c m a R$ with cat, the promoter region of the $c m a R$ gene was amplified with the primers cmaRCAT_F1 and cmaRCAT_R1, using Pyrobest Pfu polymerase (Takara). After digestion with $B a m H I$, the fragment was ligated into BamHI-treated pSK1CAT (Park et al., 2004) for the construction of pSL457. The plasmid was then electro-transformed into the $C$. ammoniagenes wild-type strain in order to generate HL1257. Plasmid pSL466 was constructed via the amplification of the cmaR coding region with the cmaR_pET_F1 and cmaR_pET_R2N primers and subsequently ligating the $\mathrm{XhoI} / \mathrm{NdeI}$-digested $\mathrm{PCR}$ product with $\mathrm{XhoI} /$ NdeI-treated pET22b (Merck Biosciences).

RNA work. Total RNA was isolated from cells at the exponential phase with $\mathrm{OD}_{600} \sim 3-4$, and first-strand cDNA synthesis was conducted as described previously (Park et al., 2007). In order to determine the transcriptional start site, $5^{\prime}$ RACE (rapid amplification of cDNA ends) was conducted with a $5^{\prime} / 3^{\prime}$ RACE kit, 2nd generation (Roche Diagnostics), in accordance with the manufacturer's instructions. Real-time RT-PCR was conducted as described by Choi et al. (2009). The standard deviation of the expression of each gene was calculated with Sequence Detection Software version 1.3.1 (Applied Biosystems). A CFX96 Real-Time PCR Detection system (Bio-Rad) was used to compare transcription levels observed in different bacterial strains (Table 2). Relative expression and the standard errors were calculated with CFX Manager software, which employs the $\Delta \Delta C_{\mathrm{t}}$ method. Normalization was performed with $16 \mathrm{~S}$ rRNA.

Enzymic assays. Corynebacterial cells were cultivated to late exponential phase and the crude extracts were prepared as previously described (Kim et al., 2004). The chloramphenicol acetyltransferase (CAT) assay was conducted in accordance with the method described by Kim et al. (2005). The enzymic activities of $O$-acetylhomoserine sulfhydrylation, cystathionine $\gamma$-synthase, and cystathionine $\beta$-lyase were determined as previously reported (Yeom et al., 2004).

Purification of $\mathrm{His}_{\mathbf{6}}-\mathrm{CmaR}$ and gel mobility shift assays. E. coli BL21 (DE3) (Merck Biosciences) harbouring pSL466 was cultivated in LB. Protein expression was induced by treating cells with $0.5 \mathrm{mM}$ IPTG at $\mathrm{OD}_{600} 0.4$. The cells were cultivated for an additional $3 \mathrm{~h}$ to fully induce protein expression. Purification of the fusion protein was conducted using HisTrap FF (GE Healthcare). The purified fusion 
protein was then dialysed and concentrated with Amicon Ultra (Millipore). Gel mobility shift assays were conducted as reported elsewhere (Suda et al., 2008). For the binding, $100 \mathrm{nM}$ DNA and $5 \mu \mathrm{M}$ purified protein were used. Each DNA fragment, as shown in Fig. 4, was amplified with the primers listed in Supplementary Table S1.

\section{RESULTS AND DISCUSSION}

\section{The cmaR gene and characteristics of the cmaR- deficient strain}

We have long been interested in biosynthetic pathways involving sulfur in C. ammoniagenes. In recent years, the transcriptional regulation of biosynthetic metabolism has become a prominent topic with regard to the genus Corynebacterium. Among the candidate regulators of sulfur metabolism, we have been most interested in $c y s R$ (NCgl0120) of C. glutamicum. It was recently studied by Rückert and co-workers, who revealed the role of the gene in encoding the dual function regulator of sulfur metabolism (Rückert et al., 2008). Subsequently, we attempted to identify the relevant genes in C. ammoniagenes, which is widely employed as an industrial nucleotide producer. An ORF encoding a CysR homologue was detected in the $C$. ammoniagenes genome database (unpublished data). However, despite the close phylogenetic relationship of $C$. ammoniagenes with $C$. glutamicum, the putative protein from $C$. ammoniagenes, which is composed of 400 amino acids with a deduced molecular mass of $42.7 \mathrm{kDa}$, evidenced only a $52.5 \%$ identity with the CysR of C. glutamicum. As the first step in studying the function of the C. ammoniagenes ORF, we determined the transcriptional start point of the $c y s R$ homologue using $5^{\prime}$ RACE. Adenine was identified as the transcriptional start point of the gene, and it clearly overlapped with the adenine of the presumed translational start (Fig. 5c). This result demonstrates that the $c y s R$ homologue is transcribed without the $5^{\prime}$ leader sequence. Moll et al. (2002) have reported that leaderless transcripts that do not harbour the Shine-Dalgarno sequence on their mRNA tend to occur more frequently in Gram-positive eubacteria than in Gram-negative bacteria. In addition, Patek et al. (2003) have compiled a list of C. glutamicum genes that harbour leaderless mRNA. Furthermore, it has recently been reported that cysR of C. glutamicum is also transcribed as a leaderless transcript (Rückert et al., 2008). Upstream of the transcriptional start site, we were able to locate a putative McbR-binding sequence within the promoter region of the gene (Fig. 5c), thereby suggesting the involvement of an $m c b R$ homologue in the regulation of the expression of the C. ammoniagenes ORF (see below). In C. glutamicum, the cysR gene ( $\mathrm{NCgl0120)}$ is thought to be under negative regulation by $M c b R$, as evidenced by the increased transcription of the gene in the $m c b R$ mutant strain (Rey et al., 2005).

In an effort to assess the function of the $c y s R$ homologue, the pertinent gene in C. ammoniagenes was deleted via a gene-disruption technique, as described in Methods. During a series of phenotypic tests, we determined that HL1168, the cysR homologue-deleted mutant, evidenced an interesting feature, namely that it was unable to grow on minimal medium. By complementing the HL1168 strain with the vector pSL433, we could corroborate that this growth defect was attributable to a deficiency of the $c y s R$ homologue. Subsequently, via an amino acid auxotrophy test, we identified HL1168 as a methionine and cysteine double auxotroph (Fig. 2a). In order to determine whether the cysteine auxotrophy of HL1168 was caused by the inability to reduce inorganic sulfur sources, we assessed growth with intermediates of the sulfur assimilation pathway, using $\left(\mathrm{NH}_{4}\right)_{2} \mathrm{SO}_{4}, \mathrm{Na}_{2} \mathrm{SO}_{3}, \mathrm{Na}_{2} \mathrm{~S}_{2} \mathrm{O}_{3}$ and $\mathrm{Na}_{2} \mathrm{~S}$ as the sole sulfur sources. Among these, only $\mathrm{Na}_{2} \mathrm{~S}$ was demonstrated to support effectively the growth of the auxotroph (Fig. 2a); this implies that the cysR homologue is necessary for the assimilation of sulfur from sulfate to sulfide, and $\mathrm{O}$-acetylserine thiolase, which is encoded by cysK (Fig. 1), did not appear to be affected by the mutation. Subsequently, we conducted another growth test to elucidate the methionine biosynthetic steps affected by the mutation. Intermediates, including $O$-acetylhomoserine, cystathionine and homocysteine, were shown to be ineffective in supporting the growth of HL1168 (data not shown). These data show that the $c y s R$ homologue is a requisite for methionine biosynthesis, as well as sulfate reduction. Thus, we named the $c y s R$ homologue $c m a R$ (cysteine and methionine regulator in C. ammoniagenes). In addition, we determined that the wild-type $C$. ammoniagenes strain had a weak ability to use methionine as the sole sulfur source (Fig. 2a), as is the case with $C$. glutamicum (Rückert \& Kalinowski, 2008). Revealing the cause of such poor growth on methionine will require the elucidation of catabolic pathways for methionine in $C$. glutamicum and C. ammoniagenes. Although no experimental evidence is available, Rückert et al. (2003), based on the genome data, suggested the presence of the reverse transsulfuration pathway in C. glutamicum.

Thus far, several positive and negative regulators of sulfur metabolism have been identified in several bacterial species (Burguière et al., 2005; Fernandez et al., 2002; Guillouard et al., 2002; van der Ploeg et al., 2001). Against our expectation, these proteins evidenced a low level of identity with $\mathrm{CmaR}$ (7\% with E. coli $\mathrm{CysB}, 5 \%$ with $B$. subtilis YtII, $6 \%$ with B. subtilis CysL and $3 \%$ with L. lactis CmbR). Similarly, regulators known to control sulfur metabolism in C. glutamicum evidenced no structural homology to known regulators from other genera (Koch et al., 2005a; Rückert et al., 2008; Rey et al., 2003). This result may indicate that the regulatory mechanism of sulfur metabolism operates in a distinctive manner in the Corynebacteria, and even among Corynebacterium species more generally.

In an effort to evaluate the functions of $c m a R$, we conducted more precise growth tests over a range of methionine concentrations. As can be observed in Fig. 2(b), 


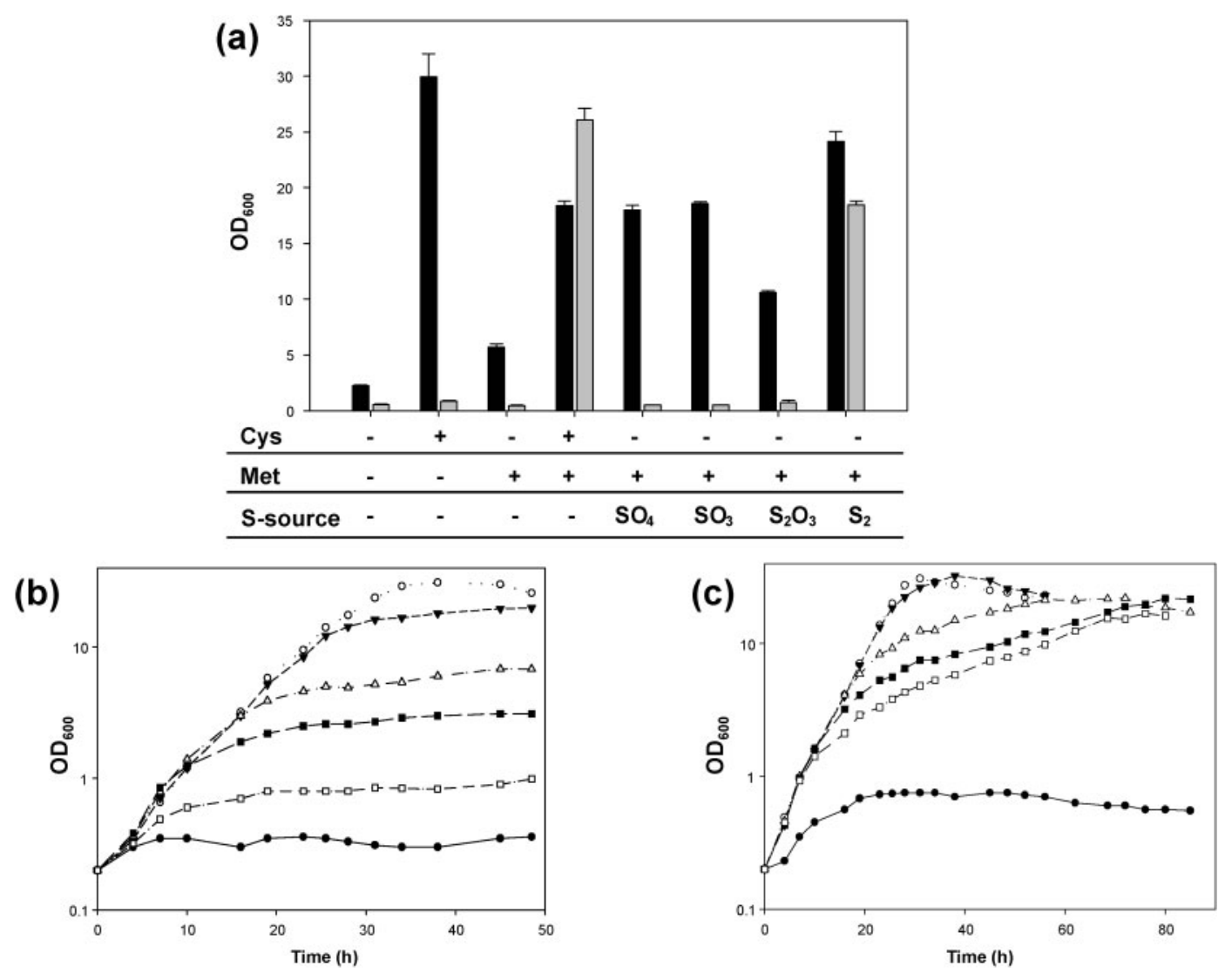

Fig. 2. Growth of cells on various sulfur sources. (a) Wild-type (black bars) and HL1168 (grey bars) strains were grown in minimal medium with the indicated sulfur sources. HL1168 (b) or wild-type (c) was grown in minimal medium containing $500 \mu \mathrm{M}$ cysteine and varying amounts of methionine. Symbols: •, no sulfur source; $\bigcirc, 500 \mu \mathrm{M}$ methionine; $\mathbf{\nabla}, 200 \mu \mathrm{M}$ methionine; $\triangle, 50 \mu \mathrm{M}$ methionine; $\mathbf{\square}, 20 \mu \mathrm{M}$ methionine; $\square, 0 \mu \mathrm{M}$ methionine.

HL1168, the $\Delta c m a R$ mutant strain, displayed only marginal growth in the absence of sulfur sources or in the presence of cysteine as the sole sulfur source. However, it did grow when methionine was added to the medium in the presence of a fixed amount of cysteine $(0.5 \mathrm{mM})$. The final cell yield was proportional to the quantity of added methionine. However, in the wild-type strain (Fig. 2c), the added methionine affected the growth rate, but not the final yield. An increase in the methionine concentration from 50 to $500 \mu \mathrm{M}$ improved the doubling time from 2.5 to $0.7 \mathrm{~h}$. In the absence of methionine, a slow growth rate with a doubling time of $5.4 \mathrm{~h}$ was noted. Collectively, these data demonstrate that $c m a R$ is required for the conversion of cysteine to methionine in C. ammoniagenes, and shows a clear distinction between $c m a R$ and $c y s R$ in functional aspects.

\section{Activity of selected methionine biosynthetic enzymes}

In order to evaluate the possible cause of the defective growth of HL1168 when cysteine was utilized as the sole sulfur source, we monitored the activities of methionine biosynthetic enzymes, including $\mathrm{O}$-acetylhomoserine sulfhydrylase (OAHSH, encoded by metY), cystathionine $\gamma$ synthase (CGS, encoded by metB) and cystathionine $\beta$ lyase (CBL, encoded by aecD). As is shown in Table 1 , the activities of OAHSH and CBL were reduced by $20 \%$ in the $\triangle c m a R$ strain. Surprisingly, CGS activity was reduced by more than $50 \%$ in the $\Delta c m a R$ strain. Furthermore, when the added methionine concentration was lowered from 0.5 to $0.25 \mathrm{mM}$ to fully induce methionine biosynthetic genes, the CGS activity achieved a level of only $23 \%$ as compared with the activity observed with the wild-type strain. The reduction of methionine biosynthetic enzyme activity resulting from $c m a R$ deficiency (Table 1) was beyond the level observed with repression (Yeom et al., 2004). On the basis of these results, we concluded that the growth defect of the mutant strain was caused, in part, by defects in the methionine biosynthetic pathway. Additionally, as is the case in C. glutamicum (Lee \& Hwang, 2003), we determined that $C$. ammoniagenes also utilizes $O$-acetylhomoserine as the substrate for OAHSH and CGS (data not shown). 
Table 1. Activities of selected enzymes of the methionine biosynthetic pathway

Crude extracts were prepared as described in Methods. Average values from two independent experiments are shown. WT, wild-type.

\begin{tabular}{|c|c|c|c|c|c|c|}
\hline \multirow[t]{3}{*}{ Enzyme $^{*}$} & \multicolumn{6}{|c|}{ Activity (nmol $\mathrm{min}^{-1} \mathrm{mg}^{-1}$ ) } \\
\hline & \multirow{2}{*}{$\begin{array}{c}\begin{array}{c}\text { Cysteine } \\
(0.5 \mathrm{mM})\end{array} \\
\text { WT }\end{array}$} & \multirow{2}{*}{$\begin{array}{c}\begin{array}{c}\text { Methionine } \\
(0.5 \mathrm{mM})\end{array} \\
\text { WT }\end{array}$} & \multicolumn{2}{|c|}{$\begin{array}{l}\text { Cysteine }(0.5 \mathrm{mM}) \text {, } \\
\text { methionine }(0.5 \mathrm{mM})\end{array}$} & \multicolumn{2}{|c|}{$\begin{array}{c}\text { Cysteine }(0.5 \mathrm{mM}) \\
\text { methionine }(0.25 \mathrm{mM})\end{array}$} \\
\hline & & & WT & $\Delta c m a R$ & WT & $\Delta c m a R$ \\
\hline OAHSH (met $Y)$ & $15 \pm 2.4$ & $12 \pm 1.9$ & $16 \pm 0.8$ & $12 \pm 1.3$ & $14 \pm 2.1$ & $12 \pm 1.5$ \\
\hline
\end{tabular}

${ }^{\star}$ Abbreviations: OAHSH, O-acetylhomoserine sulfhydrylase; CGS, cystathionine $\gamma$-synthase; CBL, cystathionine $\beta$-lyase.

\section{Transcription of methionine biosynthetic and sulfur assimilatory genes}

In order to determine whether low levels of enzyme activity of methionine biosynthetic genes in the mutant strain were caused by impaired transcription of the corresponding genes, we determined the quantity of mRNA expressed from the methionine biosynthetic genes via real-time RTPCR. Genes in the methionine pathway, including met $Y X$, $m e t F E, m e t B$ and $a e c D$, and in sulfur assimilatory routes, such as $c y s I X Y Z, c y s H D N$ and $c y s K$, were selected for the experiment. First of all, the organization of $c y s$ genes in $C$. ammoniagenes was analysed. Interestingly, in contrast to the sulfur assimilatory genes in C. glutamicum, which consisted of one operon (Rückert et al., 2005), the corresponding genes in C. ammoniagenes were divided into cysHDN and cysIXYZ operons (data not shown). Furthermore, unlike the situation in C. glutamicum, the $m e t F$ and metE genes of $C$. ammoniagenes were organized into an operon. In addition to the genes mentioned above, we also determined that the met $Y X$ genes of $C$. ammoniagenes constitute an operon, in addition to cysKE (data not shown).

As is shown in Table 2, the transcription levels of met $Y X$, $m e t B$ and $c y s I X Y Z$ in the cmaR-deficient strain were reduced by 80,50 and $90 \%$, respectively. The low transcription levels of the genes in the $\Delta c m a R$ strain were also observed at lower concentrations of methionine (Table 2 ). The gradual induction of the transcriptional level in metFE and cysHDN with decreasing methionine concentrations may be attributable to the release of repression by methionine in the wild-type strain. Although $80 \%$ of MetY activity was noted in the mutant strain (Table 1), the quantity of met $Y$ mRNA observed in the mutant strain was at a level of only 15-20\%, as compared with that of the wild-type strain (Table 2). Although the cause of such a discrepancy remains to be clearly determined, we assume that it could have been caused by differences in experimental conditions, including the growth state of the cells at the time of cell harvest, as has been observed in C. glutamicum (Glanemann et al., 2003). In contrast, the quantity of $a e c D$ and $c y s K$ transcripts detected in the $c m a R-$ deficient strain was comparable to that of the wild-type strain. The constitutive expression of $c y s K$ was consistent with the growth results on sulfide and methionine in HL1168 (Fig. 2a). It is worthwhile to note that the cysK gene of C. glutamicum is activated by CysR and repressed by McbR (Rückert et al., 2008; Rey et al., 2003). Repression of $c y s K$ as well as other genes by McbR was also observed in C. ammoniagenes (Table 2). In C. glutamicum, the role of the aecD gene is not restricted solely to methionine biosynthesis. For example, the protein product of the $a e c D$ gene functions as a cysteine desulfhydrase, performing a role in the degradation of cysteine to pyruvate, ammonia and sulfide (Wada et al., 2002). In addition, it may function as a general $\beta$-C-S lyase via $\alpha$-ammonia and $\beta$-C-S elimination activity (Rossol \& Pühler, 1992). This may be one of the reasons that aecD was not regulated by cmaR. Collectively, these data show that not only the methionine biosynthetic route but also the sulfur assimilatory pathway are under the transcriptional control of cmaR.

\section{Control of $\mathrm{cmaR}$ expression}

We have demonstrated above that $c m a R$ can positively control methionine biosynthesis and sulfur assimilation. In order to determine whether the level of $\mathrm{cmaR}$ expression is influenced by available sulfur sources, we conducted experiments employing real-time RT-PCR (Fig. 3). When methionine and cysteine were added together to the growth medium, the transcription of the $c m a R$ gene was repressed almost completely. However, when methionine or cysteine was employed as the sole sulfur source, the transcription of the $c m a R$ gene was drastically increased. Maximal expression levels were noted when methionine was utilized as the sole sulfur source. By reducing the concentration of methionine from 0.5 to $0.05 \mathrm{mM}$, we were able to further increase the transcription of the $c m a R$ gene. These data demonstrate that the $c m a R$ gene is induced to execute a regulatory role in the conversion of methionine to cysteine, or vice versa. Furthermore, these data demonstrate that the 
Table 2. Determination of relative gene expression level by real-time PCR

The expression level obtained in the wild-type under culture conditions of $0.5 \mathrm{mM}$ cysteine and $0.5 \mathrm{mM}$ methionine was arbitrarily set to 1 . Mean values from two independent experiments are shown. Standard errors $( \pm)$ are shown in parentheses. WT, wild-type.

\begin{tabular}{|c|c|c|c|c|c|c|c|c|c|c|c|c|}
\hline \multirow[t]{3}{*}{ Gene } & \multicolumn{12}{|c|}{ Cysteine (0.5 mM) } \\
\hline & \multicolumn{4}{|c|}{ Methioinine (0.5 mM) } & \multicolumn{4}{|c|}{ Methionine (0.25 mM) } & \multicolumn{4}{|c|}{ Methionine (0.1 mM) } \\
\hline & WT & $\Delta c m a R$ & $\Delta m c b R$ & $\begin{array}{c}\Delta c m a R \\
\Delta m c b R\end{array}$ & WT & $\Delta c m a R$ & $\Delta m c b R$ & $\begin{array}{c}\Delta c m a R \\
\Delta m c b R\end{array}$ & WT & $\Delta c m a R$ & $\Delta m c b R$ & $\begin{array}{c}\Delta c m a R \\
\Delta m c b R\end{array}$ \\
\hline $\operatorname{met} Y X$ & $\begin{array}{c}1 \\
(0.23)\end{array}$ & $\begin{array}{l}0.19 \\
(0.04)\end{array}$ & $\begin{array}{c}101 \\
(15.9)\end{array}$ & $\begin{array}{l}0.62 \\
(0.18)\end{array}$ & $\begin{array}{l}1.48 \\
(0.31)\end{array}$ & $\begin{array}{l}0.22 \\
(0.03)\end{array}$ & $\begin{array}{l}84.6 \\
(4.90)\end{array}$ & $\begin{array}{l}0.63 \\
(0.07)\end{array}$ & $\begin{array}{l}1.11 \\
(0.18)\end{array}$ & $\begin{array}{l}0.22 \\
(0.04)\end{array}$ & $\begin{array}{l}91.1 \\
(16.1)\end{array}$ & $\begin{array}{l}0.77 \\
(0.14)\end{array}$ \\
\hline $\operatorname{met} B$ & $\begin{array}{c}1 \\
(0.20)\end{array}$ & $\begin{array}{l}0.33 \\
(0.04)\end{array}$ & $\begin{array}{l}22.3 \\
(3.44)\end{array}$ & $\begin{array}{l}5.37 \\
(1.56)\end{array}$ & $\begin{array}{l}0.90 \\
(0.18)\end{array}$ & $\begin{array}{l}0.45 \\
(0.04)\end{array}$ & $\begin{array}{l}18.3 \\
(2.35)\end{array}$ & $\begin{array}{l}6.56 \\
(1.27)\end{array}$ & $\begin{array}{l}1.00 \\
(0.16)\end{array}$ & $\begin{array}{l}0.55 \\
(0.10)\end{array}$ & $\begin{array}{l}10.5 \\
(1.86)\end{array}$ & $\begin{array}{l}7.90 \\
(0.64)\end{array}$ \\
\hline $\operatorname{aec} D$ & $\begin{array}{c}1 \\
(0.09)\end{array}$ & $\begin{array}{l}1.48 \\
(0.26)\end{array}$ & $\begin{array}{l}3.72 \\
(0.61)\end{array}$ & $\begin{array}{l}1.46 \\
(0.23)\end{array}$ & $\begin{array}{l}1.22 \\
(0.07)\end{array}$ & $\begin{array}{l}1.79 \\
(0.11)\end{array}$ & $\begin{array}{l}5.93 \\
(0.35)\end{array}$ & $\begin{array}{l}1.30 \\
(0.16)\end{array}$ & $\begin{array}{l}1.53 \\
(0.14)\end{array}$ & $\begin{array}{l}1.54 \\
(0.04)\end{array}$ & $\begin{array}{l}3.09 \\
(0.58)\end{array}$ & $\begin{array}{l}1.55 \\
(0.18)\end{array}$ \\
\hline metFE & $\begin{array}{c}1 \\
(0.06)\end{array}$ & $\begin{array}{l}0.89 \\
(0.07)\end{array}$ & $\begin{array}{l}352 \\
(39.7)\end{array}$ & $\begin{array}{l}5.33 \\
(1.57)\end{array}$ & $\begin{array}{l}1.68 \\
(0.22)\end{array}$ & $\begin{array}{l}1.12 \\
(0.07)\end{array}$ & $\begin{array}{l}373 \\
(18.4)\end{array}$ & $\begin{array}{l}5.54 \\
(0.64)\end{array}$ & $\begin{array}{l}3.31 \\
(0.28)\end{array}$ & $\begin{array}{l}0.99 \\
(0.12)\end{array}$ & $\begin{array}{l}300 \\
(35.1)\end{array}$ & $\begin{array}{l}5.70 \\
(0.56)\end{array}$ \\
\hline$c y s K$ & $\begin{array}{c}1 \\
(0.18)\end{array}$ & $\begin{array}{l}0.95 \\
(0.11)\end{array}$ & $\begin{array}{l}11.1 \\
(1.57)\end{array}$ & $\begin{array}{l}5.45 \\
(1.62)\end{array}$ & $\begin{array}{l}1.00 \\
(0.20)\end{array}$ & $\begin{array}{l}0.90 \\
(0.06)\end{array}$ & $\begin{array}{l}12.0 \\
(1.85)\end{array}$ & $\begin{array}{l}5.58 \\
(0.93)\end{array}$ & $\begin{array}{l}0.72 \\
(0.09)\end{array}$ & $\begin{array}{l}0.71 \\
(0.13)\end{array}$ & $\begin{array}{l}6.29 \\
(1.33)\end{array}$ & $\begin{array}{l}5.42 \\
(0.80)\end{array}$ \\
\hline cysIXYZ & $\begin{array}{c}1 \\
(0.20)\end{array}$ & $\begin{array}{l}0.11 \\
(0.02)\end{array}$ & $\begin{array}{l}46.5 \\
(7.72)\end{array}$ & $\begin{array}{l}0.73 \\
(0.22)\end{array}$ & $\begin{array}{l}1.46 \\
(0.42)\end{array}$ & $\begin{array}{l}0.10 \\
(0.02)\end{array}$ & $\begin{array}{l}45.9 \\
(3.60)\end{array}$ & $\begin{array}{l}0.77 \\
(0.09)\end{array}$ & $\begin{array}{l}1.49 \\
(0.18)\end{array}$ & $\begin{array}{l}0.11 \\
(0.02)\end{array}$ & $\begin{array}{l}33.8 \\
(8.88)\end{array}$ & $\begin{array}{l}0.82 \\
(0.07)\end{array}$ \\
\hline cysHDN & $\begin{array}{c}1 \\
(0.20)\end{array}$ & $\begin{array}{l}0.66 \\
(0.07)\end{array}$ & $\begin{array}{l}24.0 \\
(3.86)\end{array}$ & $\begin{array}{l}1.19 \\
(0.37)\end{array}$ & $\begin{array}{l}1.13 \\
(0.20)\end{array}$ & $\begin{array}{l}0.64 \\
(0.11)\end{array}$ & $\begin{array}{l}38.8 \\
(2.06)\end{array}$ & $\begin{array}{l}1.15 \\
(0.13)\end{array}$ & $\begin{array}{l}1.23 \\
(0.16)\end{array}$ & $\begin{array}{l}0.56 \\
(0.13)\end{array}$ & $\begin{array}{l}23.0 \\
(4.10)\end{array}$ & $\begin{array}{l}1.02 \\
(0.21)\end{array}$ \\
\hline
\end{tabular}

low-level expression of the methionine and sulfur assimilatory genes in the $\Delta c m a R$ strain is attributable to the absence of the cmaR gene, which probably encodes an activator. The mechanism by which methionine and/or cysteine regulates $c m a R$ gene transcription remains to be clearly elucidated.

Thus far, we have evaluated the relative level of $c m a R$ transcription via real-time RT-PCR. In order to determine the absolute level of cmaR expression, we constructed a

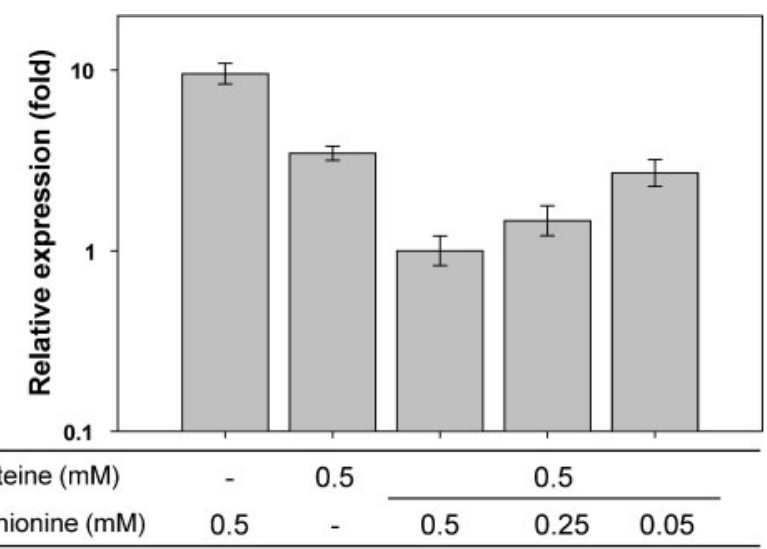

Fig. 3. Expression level of $c m a R$ as determined by real-time RTPCR conducted as described in Methods. The level of transcription achieved under the conditions of methionine and cysteine addition was arbitrarily set to 1 and utilized as a calibrator of relative quantification. Error bars, SD. vector $\left(\mathrm{P}_{c m a R}: \mathrm{CAT}\right)$ harbouring a cat gene fused to the downstream portion of the $c m a R$ promoter. As is shown in Table 3, the promoter of $c m a R$ was shown to be relatively weak. Only one-tenth of the activity was observed with the $\mathrm{P}_{\text {cmaR }}$ promoter as compared with the activity observed with the strong promoter $\mathrm{P}_{180}$. It has been well-established that genes encoding transcriptional regulatory proteins are generally expressed at low levels. However, in contrast to the data obtained with real-time RT-PCR, maximal $c m a R$ gene expression was noted when cysteine was employed as the sole sulfur source. This may be attributable to the intrinsic limitations of the assay employing cat genes as reporter genes (Shaw, 1975). Further research will be required to determine why such discrepancies arise.

\section{DNA-binding activity of CmaR}

After the identification of the involvement of $c m a R$ in controlling the expression of genes involved in sulfur metabolism, we determined the ability of the purified $\mathrm{CmaR}$ to bind to the promoter region of its target genes. First of all, the CmaR protein was purified as described in Methods. Unlike CysR of C. glutamicum (Rückert et al., 2008), CmaR could be purified without the incorporation of detergent into the column elution buffer, thereby suggesting the existence of intrinsic differences between the two proteins. Subsequently, we conducted gel mobility shift assays with a list of DNA fragments. As is shown in Fig. 4, retarded bands were noted for DNA fragments harbouring the promoter regions of cysIXY, cysHDN, metFE, met $Y X$ and metB. No band shift was observed with the promoter and the ORF region of the gapB gene, which 
(a)
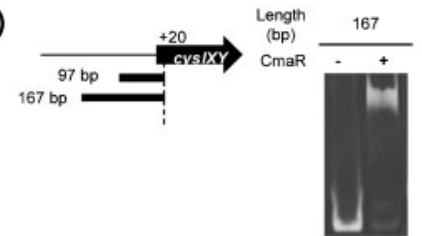

(b)
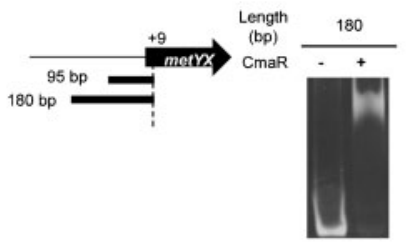

(c)

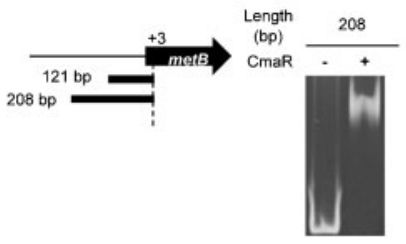

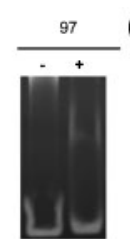
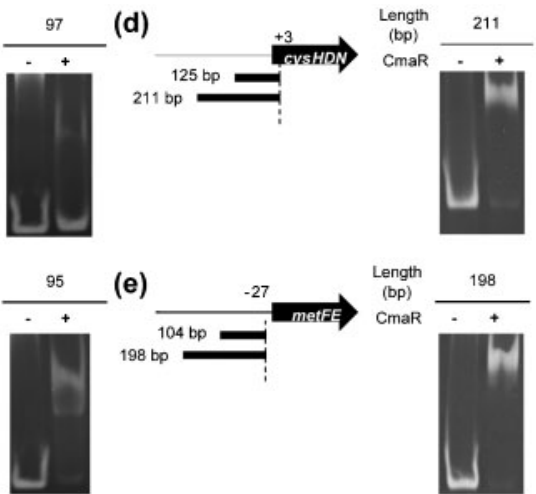

(e)
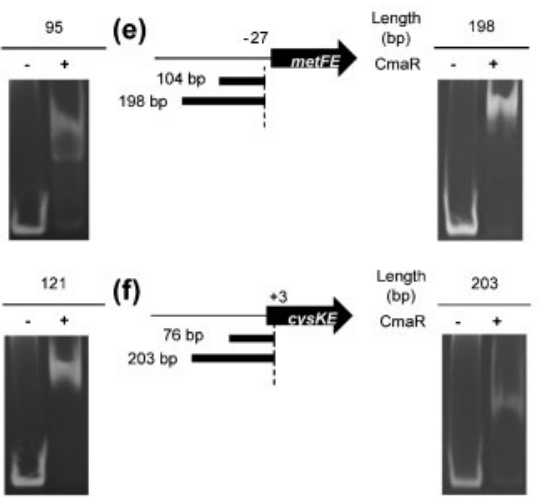

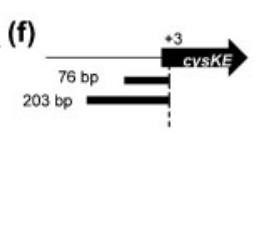

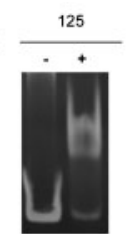

(g)
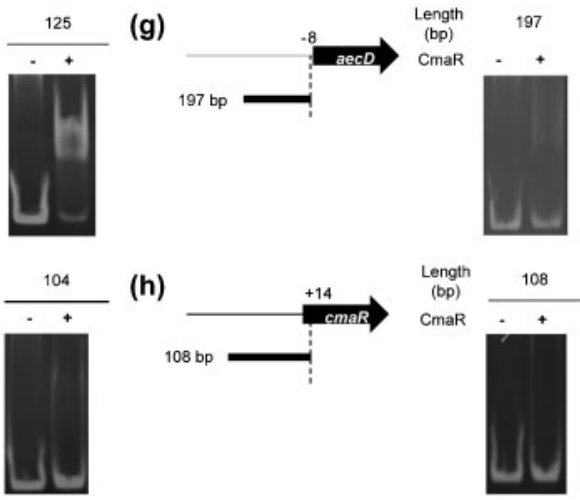

(h)

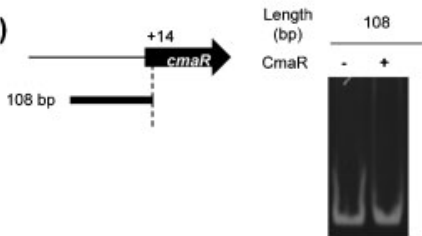

(i)

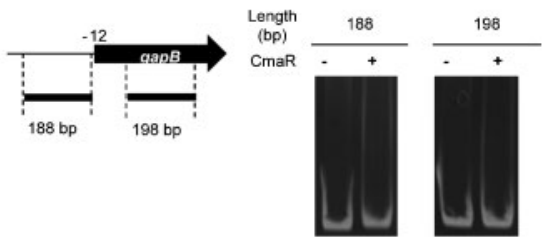

Fig. 4. DNA binding of the purified $\mathrm{CmaR}$ protein to the promoter regions of genes involved in sulfur metabolism. Gel mobility shift assays were conducted as described in Methods. Depending on the gene, one of the two different fragments of approximately 100 or $200 \mathrm{bp}$ in length measured from the translational start site was employed in each binding reaction. Bands were separated by $6 \%$ Tris-borate EDTA (TBE)-PAGE and visualized after staining with ethidium bromide. The translational start site was arbitrarily set to +1. Panels: (a), cysIXY; (b), metYX; (c), metB; (d), cysHDN; (e), metFE; (f), cysKE; (g), aecD; (h), cmaR; (i), gapB.

(a)

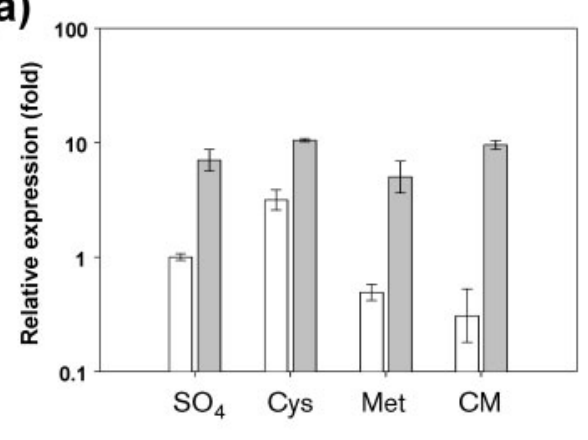

(b)

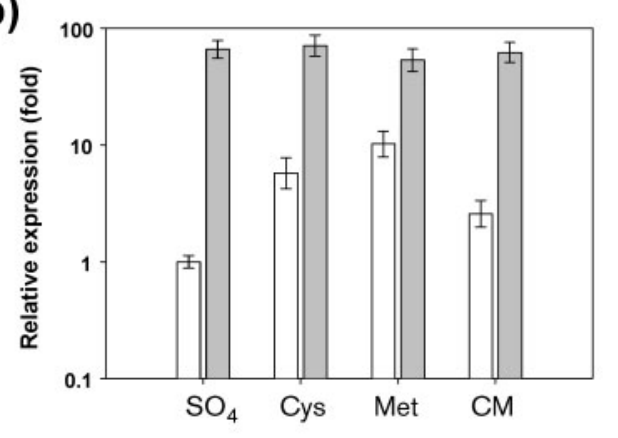

(c)

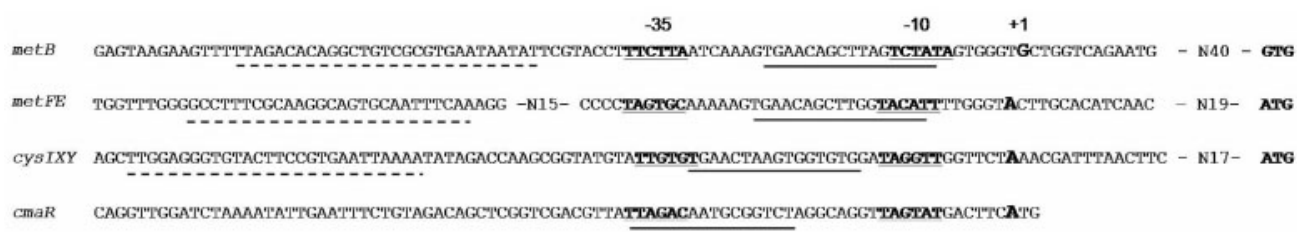

Fig. 5. Effect of $m c b R$ deletion on the expression of $m e t B(a)$ and $c m a R(b)$, and the location of CmaR-binding sequences on the $\mathrm{cmaR}$-regulated genes (c). Sulfur sources were added to a final concentration of $1 \mathrm{mM}$. The level of transcription in the wildtype (white bars) or $\Delta m c b R$ strain (grey bars) obtained when $1 \mathrm{mM}$ sulfate $\left(\mathrm{SO}_{4}\right)$ was added to the growth medium was arbitrarily set to 1 and utilized as a calibrator of relative quantification. Error bars, SD. Transcriptional start sites were determined via 5' RACE (c). Solid and dashed lines indicate McbR-binding sites and putative CmaR-binding sequences, respectively. See text for details. Cys, cysteine; Met, methionine; CM, cysteine + methionine. 
Table 3. Expression of $\mathrm{cmaR}$

C. ammoniagenes cells were cultivated in FMCAS medium. Preparation of cell extracts and determination of CAT activities were performed as described in Methods.

\begin{tabular}{|c|c|c|c|}
\hline Plasmid ${ }^{\star}$ & Properties & $\begin{array}{l}\text { Sulfur source } \\
\text { (1 mM each) }\end{array}$ & 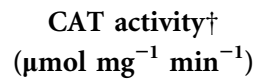 \\
\hline pSK1CAT & Empty vector & Cys + Met & $0.03 \pm 0.01$ \\
\hline pSK1CAT $:: \mathrm{P}_{180}$ & Overexpression of CAT & Cys + Met & $24.9 \pm 4.20$ \\
\hline \multirow[t]{3}{*}{ pSL457 } & $\mathrm{P}_{c m a R}:: \mathrm{CAT}$ & Cysteine & $2.8 \pm 0.20$ \\
\hline & & Methionine & $1.1 \pm 0.05$ \\
\hline & & Cys + Met & $0.6 \pm 0.02$ \\
\hline
\end{tabular}

${ }^{\star}$ Plasmids pSK1CAT and pSK1CAT : $: \mathrm{P}_{180}$ have been described previously by Park et al. (2004).

$\dagger$ Mean values from three independent experiments are shown.

was utilized as a negative control (Fig. 4i). In accordance with the transcriptional and enzymic data (Tables 1 and 2), no shifted bands were observed with aecD. These data demonstrate that the $\mathrm{CmaR}$ protein functions as a transcriptional activator which controls the expression of genes involved in sulfur metabolism, as well as methionine biosynthesis. In order to determine the CmaR-binding site on each DNA, we conducted an experiment with two different fragments of approximately 100 and $200 \mathrm{bp}$ in length, as measured from the translational start site (Fig. 4). For the met $Y X$, metB and $c y s H D N$ genes, a band shift was noted with smaller DNA fragments. For metFE, band shifts were only noted with longer fragments. For cysIXY, although a major shift was observed with longer fragments, a weak shift was also noted with smaller fragments, thereby suggesting the presence of a CmaR-binding site near the upstream boundary of the smaller fragments. Contrary to the enzymic and transcriptional data, we observed the binding of the $\mathrm{CmaR}$ protein to the promoter region of $c y s K E$ (Fig. 4f). Judging from the weakness of the band shift, we speculated that the shift was induced by the nonspecific interaction of $\mathrm{CmaR}$ with the DNA fragments. Rückert et al. (2008) also noted a non-specific interaction of the CysR protein with its target DNA. Further research will be required to determine the reasons for such a discrepancy. In addition, as is shown in Fig. 4(h), the CmaR protein did not bind to the promoter region of $c m a R$. This implies that the $c m a R$ gene does not control its own expression, excluding the possibility of autoregulation.

Interestingly, CmaR did not require any modulators for its binding to target DNAs (Fig. 4). In E. coli, the activity of the CysB protein is modulated by effectors, including $\mathrm{N}$ acetylserine (NAS) and OAS (Ostrowski \& Kredich, 1989), although its binding to DNA can be shown in the absence of such effectors in vitro. In addition, sulfide and thiosulfate function as negative effectors to inhibit the binding of CysB to DNA (Ostrowski \& Kredich, 1990). Furthermore, the CysR of C. glutamicum requires OAH or OAS as a positive effector (Rückert et al., 2008). DNA binding of the CysR protein was possible only in the presence of such effectors.
However, unlike CysR, CmaR required no effectors to bind to its target DNAs (Fig. 4). To monitor carefully the effects of possible effectors on the binding of $\mathrm{CmaR}$ to DNA, the DNA-binding assay was conducted with minimal protein concentrations, which resulted in a partial DNA shift of approximately $50 \%$. The incorporation of possible effectors, such as methionine, cysteine, OAS, OAH, sulfide, thiosulfate and SAM, in the assay mixture did not influence the pattern of band shifts (data not shown), thereby suggesting that the functional mechanism exerted by the CmaR protein of $C$. ammoniagenes differs from that of the CysR of $C$. glutamicum. This is in accordance with the data shown above which indicate that the expression of the cmaR gene is controlled at the level of transcription (Fig. 3), excluding the involvement of effectors. The data indicate that the mechanism by which the CmaR protein exerts its regulatory effect is via the control of the expression of the cmaR gene, rather than by modulating the activity of $\mathrm{CmaR}$ through effectors, as is the case for CysR. In Burkholderia cenocepacia and $P$. putida, the binding of the activator to the cys genes does not require effector molecules (Iwanicka-Nowicka et al., 2007; Kouzuma et al., 2008).

Knowing that CmaR binds to its target DNAs, we identified possible CmaR-binding sites on the regulatory regions of several genes with mapped transcriptional start sites. To accomplish this, we utilized the CysR-binding sequences of C. glutamicum (Rückert et al., 2008). As is shown in Fig. 5(c), putative CysR-binding sequences could be located in the upstream region of the -35 promoter sequences of the met $B$, metFE and cysIXY genes. We speculate that the sequences function as CmaR-binding sites in C. ammoniagenes. In addition, McbR-binding sequences could be located between the -10 and -35 promoter sequences of the genes. These results suggest that the $\mathrm{cmaR}$ gene operates as a positive regulator for the subset of genes under the control of McbR.

\section{Effect of $m c b R$ and $c m a R / m c b R$ deficiency}

The TetR-type regulator McbR has been demonstrated to repress many of the genes involved in methionine and 
cysteine metabolism in C. glutamicum. Under methionineabundance conditions, the intracellular level of SAM is elevated. Subsequently, SAM binds to McbR, and the complex represses a range of methionine and cysteine biosynthetic genes (Suda et al., 2008). Besides SAM, SAH also functions as a negative effector of McbR (Rey et al., 2005). Recently, the regulatory model of sulfur metabolism in C. glutamicum has been proposed (Rückert et al., 2008). According to this model, McbR functions as a master regulator of sulfur metabolism via the repression of genes that include $c y s R$ and $s s u R$. When released from the repression, CysR activates genes such as cysIXHDNYZ, fpr2, $\operatorname{cg} 3372-75, \operatorname{cg} 1514, \operatorname{cg} 4005$ and $s s u R$. No ssuR homologue is present in the C. ammoniagenes genome (data not shown). Subsequently, we assessed the expression of genes involved in sulfur metabolism in the $m c b R$-deficient mutant strain $(\Delta m c b R)$. As is shown in Fig. 5(b), the transcription of $c m a R$ in the $\Delta m c b R$ strain was increased dramatically, as compared with that of the wild-type strain. This shows that McbR represses cmaR expression in C. ammoniagenes. In addition, as shown in Fig. 5(a), metB expression was also increased in the $\triangle m c b R$ strain, thereby indicating the repressive function of McbR in methionine biosynthesis in the organism. This phenomenon was also observed with metYX, metFE, cysIXY, cysHDN and cysK (Table 2). Derepressed transcription of the genes in the $\Delta m c b R$ strain was markedly diminished in the $\Delta c m a R \Delta m c b R$ double mutant strain, suggesting a critical role for the $c m a R$ gene in the transcription of the genes (Table 2). The degree of influence on the transcription of the aecD and cysK genes of the mutations was relatively small. In addition to its role as an activator, CysR is also known to repress genes such as cg2810 and cg3138-39 in C. glutamicum (Rückert et al., 2008). In order to determine whether CmaR functions in such a manner, we monitored the expression of the $C$. ammoniagenes gene which corresponds to cg2810. As compared with the wild-type strain, the expression level of the gene in the $\triangle c m a R$ mutant strain was unchanged (data not shown), thereby suggesting that there are differences in the mechanisms by which the $c m a R$ and $c y s R$ genes exert their regulatory effects.

In conclusion, we present evidence in this study that $\mathrm{CmaR}$ positively controls not only the methionine biosynthetic and sulfur assimilatory pathways, but also conversion between cysteine and methionine. In addition, we have demonstrated that the presence of methionine or cysteine stimulates $c m a R$ expression. Furthermore, the $c m a R$ gene is negatively controlled by McbR, as is the case in $C$. glutamicum. In accordance with the physiological, genetic and biochemical data, we observed the direct binding of the purified CmaR protein to the promoter region of its target genes in the absence of any effector molecules. These results demonstrated that the $c m a R$ gene of C. ammoniagenes plays a role similar to but distinct from that of the functional homologue $c y s R$ of $C$. glutamicum. Although not all genes and enzymes in sulfur metabolism have been identified in $C$. ammoniagenes, cmaR may prove an attractive target for the development of methionine- or cysteine-producing strains.

\section{ACKNOWLEDGEMENTS}

We thank Daesang Co. for providing the sequences of $C$. ammoniagenes. This work was supported by a Korea Research Foundation Grant funded by the Korean Government (KRF-2006F00002 to H.-S. L.).

\section{REFERENCES}

Adams, A. \& Kaiser, C. (1998). Methods in Yeast Genetics: a Cold Spring Harbor Laboratory course manual, 1997 edn. Plainview, NY: Cold Spring Harbor Laboratory.

Burguière, P., Fert, J., Guillouard, I., Auger, S., Danchin, A. \& MartinVerstraete, I. (2005). Regulation of the Bacillus subtilis ytmI operon, involved in sulfur metabolism. J Bacteriol 187, 6019-6030.

Choi, W. W., Park, S. D., Lee, S. M., Kim, H. B., Kim, Y. \& Lee, H. S. (2009). The $w h c A$ gene plays a negative role in oxidative stress response of Corynebacterium glutamicum. FEMS Microbiol Lett 290, 32-38.

Even, S., Burguière, P., Auger, S., Soutourina, O., Danchin, A. \& Martin-Verstraete, I. (2006). Global control of cysteine metabolism by CymR in Bacillus subtilis. J Bacteriol 188, 2184-2197.

Fernandez, M., Kleerebezem, M., Kuipers, O. P., Siezen, R. J. \& van Kranenburg, R. (2002). Regulation of the $m e t C$-cysK operon, involved in sulfur metabolism in Lactococcus lactis. J Bacteriol 184, 82-90.

Follettie, M. T., Peoples, O. P., Agoropoulou, C. \& Sinskey, A. J. (1993). Gene structure and expression of the Corynebacterium flavum N13 ask-asd operon. J Bacteriol 175, 4096-4103.

Glanemann, C., Loos, A., Gorret, N., Willis, L. B., O’Brien, X. M., Lessard, P. A. \& Sinskey, A. J. (2003). Disparity between changes in mRNA abundance and enzyme activity in Corynebacterium glutamicum: implications for DNA microarray analysis. Appl Microbiol Biotechnol 61, 61-68.

Grant, S. G., Jessee, J., Bloom, F. R. \& Hanahan, D. (1990). Differential plasmid rescue from transgenic mouse DNAs into Escherichia coli methylation-restriction mutants. Proc Natl Acad Sci U S A 87, 4645-4649.

Guillouard, I., Auger, S., Hullo, M. F., Chetouani, F., Danchin, A. \& Martin-Verstraete, I. (2002). Identification of Bacillus subtilis CysL, a regulator of the cysJI operon, which encodes sulfite reductase. J Bacteriol 184, 4681-4689.

Haitani, Y., Awano, N., Yamazaki, M., Wada, M., Nakamori, S. \& Takagi, H. (2006). Functional analysis of L-serine $O$-acetyltransferase from Corynebacterium glutamicum. FEMS Microbiol Lett 255, 156-163.

Hullo, M. F., Auger, S., Soutourina, O., Barzu, O., Yvon, M., Danchin, A. \& Martin-Verstraete, I. (2007). Conversion of methionine to cysteine in Bacillus subtilis and its regulation. J Bacteriol 189, 187-197.

Hwang, B. J., Kim, Y., Kim, H. B., Hwang, H. J., Kim, J. H. \& Lee, H. S. (1999). Analysis of Corynebacterium glutamicum methionine biosynthetic pathway: isolation and analysis of metB encoding cystathionine gamma-synthase. Mol Cells 9, 300-308.

Hwang, B. J., Yeom, H. J., Kim, Y. \& Lee, H. S. (2002). Corynebacterium glutamicum utilizes both transsulfuration and direct sulfhydrylation pathways for methionine biosynthesis. J Bacteriol 184, 1277-1286. 
Iwanicka-Nowicka, R. \& Hryniewicz, M. M. (1995). A new gene, $c b l$, encoding a member of the LysR family of transcriptional regulators belongs to Escherichia coli cys regulon. Gene 166, 11-17.

Iwanicka-Nowicka, R., Zielak, A., Cook, A. M., Thomas, M. S. \& Hryniewicz, M. M. (2007). Regulation of sulfur assimilation pathways in Burkholderia cenocepacia: identification of transcription factors CysB and SsuR and their role in control of target genes. J Bacteriol 189, 1675-1688.

Kim, J. W., Kim, H. J., Kim, Y., Lee, M. S. \& Lee, H. S. (2001). Properties of the Corynebacterium glutamicum metC gene encoding cystathionine $\beta$-lyase. Mol Cells 11, 220-225.

Kim, H. J., Kim, T. H., Kim, Y. \& Lee, H. S. (2004). Identification and characterization of $g l x R$, a gene involved in regulation of glyoxylate bypass in Corynebacterium glutamicum. J Bacteriol 186, 3453-3460.

Kim, T. H., Kim, H. J., Park, J. S., Kim, Y., Kim, P. \& Lee, H. S. (2005). Functional analysis of sigH expression in Corynebacterium glutamicum. Biochem Biophys Res Commun 331, 1542-1547.

Koch, D. J., Rückert, C., Albersmeier, A., Hüser, A. T., Tauch, A., Pühler, A. \& Kalinowski, J. (2005a). The transcriptional regulator SsuR activates expression of the Corynebacterium glutamicum sulphonate utilization genes in the absence of sulphate. Mol Microbiol 58, 480-494.

Koch, D. J., Rückert, C., Rey, D. A., Mix, A., Pühler, A. \& Kalinowski, J. (2005b). Role of the ssu and seu genes of Corynebacterium glutamicum ATCC 13032 in utilization of sulfonates and sulfonate esters as sulfur sources. Appl Environ Microbiol 71, 6104-6114.

Kouzuma, A., Endoh, T., Omori, T., Nojiri, H., Yamane, H. \& Habe, H. (2008). Transcription factors CysB and SfnR constitute the hierarchical regulatory system for the sulfate starvation response in Pseudomonas putida. J Bacteriol 190, 4521-4531.

Kredich, N. M. (1996). Biosynthesis of cysteine. In Escherichia coli and Salmonella: Cellular and Molecular Biology, 2nd edn. pp. 514-527. Edited by F. C. Neidhardt and others. Washington, DC: American Society for Microbiology.

Lee, H. S. (2005). Sulfur metabolism and its regulation. In Handbook of Corynebacterium glutamicum, pp. 351-376. Edited by L. Eggeling \& M. Bott. Boca Raton, FL: Taylor \& Francis.

Lee, H. S. \& Hwang, B. J. (2003). Methionine biosynthesis and its regulation in Corynebacterium glutamicum: parallel pathways of transsulfuration and direct sulfhydrylation. Appl Microbiol Biotechnol 62, 459-467.

Liebl, W. (2006). Corynebacterium - Nonmedical. In The Prokaryotes: a Handbook on the Biology of Bacteria, 3rd edn, pp. 796-818. Edited by M. Dworkin, S. Falkow, E. Rosenberg, K.-H. Schleifer \& E. Stackebrandt. New York: Springer.

Link, A. J., Phillips, D. \& Church, G. M. (1997). Methods for generating precise deletions and insertions in the genome of wild-type Escherichia coli: application to open reading frame characterization. J Bacteriol 179, 6228-6237.

MacNeil, D. J., Occi, J. L., Gewain, K. M., MacNeil, T., Gibbons, P. H., Ruby, C. L. \& Danis, S. J. (1992). Complex organization of the Streptomyces avermitilis genes encoding the avermectin polyketide synthase. Gene 115, 119-125.

Moll, I., Grill, S., Gualerzi, C. O. \& Blasi, U. (2002). Leaderless mRNAs in bacteria: surprises in ribosomal recruitment and translational control. Mol Microbiol 43, 239-246.

Ostrowski, J. \& Kredich, N. M. (1989). Molecular characterization of the cysJIH promoters of Salmonella typhimurium and Escherichia coli: regulation by cysB protein and $N$-acetyl-L-serine. J Bacteriol 171, 130-140.

Ostrowski, J. \& Kredich, N. M. (1990). In vitro interactions of CysB protein with the cysIIH promoter of Salmonella typhimurium: inhibitory effects of sulfide. J Bacteriol 172, 779-785.
Park, S. D., Lee, J. Y., Kim, Y., Kim, J. H. \& Lee, H. S. (1998). Isolation and analysis of metA, a methionine biosynthetic gene encoding homoserine acetyltransferase in Corynebacterium glutamicum. Mol Cells 8, 286-294.

Park, S. D., Lee, S. N., Park, I. H., Choi, J. S., Jeong, W. K., Kim, Y. H. \& Lee, H. S. (2004). Isolation and characterization of transcriptional elements from Corynebacterium glutamicum. J Microbiol Biotechnol 14, 789-795.

Park, S. D., Lee, J. Y., Sim, S. Y., Kim, Y. \& Lee, H. S. (2007). Characteristics of methionine production by an engineered Corynebacterium glutamicum strain. Metab Eng 9, 327-336.

Patek, M., Nesvera, J., Guyonvarch, A., Reyes, O. \& Leblon, G. (2003). Promoters of Corynebacterium glutamicum. J Biotechnol 104, 311-323.

Rey, D. A., Pühler, A. \& Kalinowski, J. (2003). The putative transcriptional repressor McbR, member of the TetR-family, is involved in the regulation of the metabolic network directing the synthesis of sulfur containing amino acids in Corynebacterium glutamicum. J Biotechnol 103, 51-65.

Rey, D. A., Nentwich, S. S., Koch, D. J., Rückert, C., Pühler, A., Tauch, A. \& Kalinowski, J. (2005). The McbR repressor modulated by the effector substance $S$-adenosylhomocysteine controls directly the transcription of a regulon involved in sulphur metabolism of Corynebacterium glutamicum ATCC 13032. Mol Microbiol 56, 871-887.

Rossol, I. \& Pühler, A. (1992). The Corynebacterium glutamicum aecD gene encodes a $\mathrm{C}-\mathrm{S}$ lyase with $\alpha, \beta$-elimination activity that degrades aminoethylcysteine. J Bacteriol 174, 2968-2977.

Rückert, C. \& Kalinowski, J. (2008). Sulfur metabolism in Corynebacterium glutamicum. In Corynebacteria: Genomics and Molecular Biology, pp. 117-240. Edited by A. Burkowski. Norwich, UK: Caister Academic Press.

Rückert, C., Pühler, A. \& Kalinowski, J. (2003). Genome-wide analysis of the L-methionine biosynthetic pathway in Corynebacterium glutamicum by targeted gene deletion and homologous complementation. J Biotechnol 104, 213-228.

Rückert, C., Koch, D. J., Rey, D. A., Albersmeier, A., Mormann, S., Pühler, A. \& Kalinowski, J. (2005). Functional genomics and expression analysis of the Corynebacterium glutamicum fpr2cysIXHDNYZ gene cluster involved in assimilatory sulphate reduction. BMC Genomics 6, 121.

Rückert, C., Milse, J., Albersmeier, A., Koch, D. J., Pühler, A. \& Kalinowski, J. (2008). The dual transcriptional regulator CysR in Corynebacterium glutamicum ATCC13032 controls a subset of genes of the McbR regulon in response to the availability of sulphide acceptor molecules. BMC Genomics 9, 483.

Schäfer, A., Tauch, A., Jager, W., Kalinowski, J., Thierbach, G. \& Pühler, A. (1994). Small mobilizable multi-purpose cloning vectors derived from the Escherichia coli plasmids pK18 and pK19: selection of defined deletions in the chromosome of Corynebacterium glutamicum. Gene 145, 69-73.

Shaw, W. V. (1975). Chloramphenicol acetyltransferase from chloramphenicol-resistant bacteria. Methods Enzymol 43, 737-755.

Sperandio, B., Polard, P., Ehrlich, D. S., Renault, P. \& Guedon, E. (2005). Sulfur amino acid metabolism and its control in Lactococcus lactis IL1403. J Bacteriol 187, 3762-3778.

Suda, M., Teramoto, H., Imamiya, T., Inui, M. \& Yukawa, H. (2008). Transcriptional regulation of Corynebacterium glutamicum methionine biosynthesis genes in response to methionine supplementation under oxygen deprivation. Appl Microbiol Biotechnol 81, 505-513.

Tanous, C., Soutourina, O., Raynal, B., Hullo, M. F., Mervelet, P., Gilles, A. M., Noirot, P., Danchin, A., England, P. \& Martin-Verstraete, I. 
(2008). The CymR regulator in complex with the enzyme CysK controls cysteine metabolism in Bacillus subtilis. J Biol Chem 283, 35551-35560.

van der Ploeg, J. R., Iwanicka-Nowicka, R., Kertesz, M. A., Leisinger, T. \& Hryniewicz, M. M. (1997). Involvement of CysB and Cbl regulatory proteins in expression of the $\operatorname{tau} A B C D$ operon and other sulfate starvation-inducible genes in Escherichia coli. J Bacteriol 179, 76717678.

van der Ploeg, J. R., Eichhorn, E. \& Leisinger, T. (2001). Sulfonatesulfur metabolism and its regulation in Escherichia coli. Arch Microbiol 176, 1-8.

Vermeij, P. \& Kertesz, M. A. (1999). Pathways of assimilative sulfur metabolism in Pseudomonas putida. J Bacteriol 181, 5833-5837.

Wada, M., Awano, N., Haisa, K., Takagi, H. \& Nakamori, S. (2002). Purification, characterization and identification of cysteine desulfhy- drase of Corynebacterium glutamicum, and its relationship to cysteine production. FEMS Microbiol Lett 217, 103-107.

Wada, M., Awano, N., Yamazawa, H., Takagi, H. \& Nakamori, S. (2004). Purification and characterization of $O$-acetylserine sulfhydrylase of Corynebacterium glutamicum. Biosci Biotechnol Biochem 68, 1581-1583.

Wheeler, P. R., Coldham, N. G., Keating, L., Gordon, S. V., Wooff, E. E., Parish, T. \& Hewinson, R. G. (2005). Functional demonstration of reverse transsulfuration in the Mycobacterium tuberculosis complex reveals that methionine is the preferred sulfur source for pathogenic mycobacteria. J Biol Chem 280, 8069-8078.

Yeom, H. J., Hwang, B. J., Lee, M. S., Kim, Y. H. \& Lee, H. S. (2004). Regulation of enzymes involved in methionine biosynthesis in Corynebacterium glutamicum. J Microbiol Biotechnol 14, 373-378.

Edited by: M. A. Kertesz 